\title{
The Effect Of Social Pressures On CEO Compensation
}

\author{
Gregory L. Nagel, Middle Tennessee State University, USA
}

Denise M. Leggett, Middle Tennessee State University, USA

\begin{abstract}
We find that social pressures have a positive effect on CEO compensation. Social pressures come from frequent interactions with other CEOs, wealthy people, and social elites in the local area; from attending industry events; and from comparing luxury homes. Pay premiums associated with social pressures (social premiums) are calculated after incorporating the effect of other known pay determinants. We show that social premiums are lower when the physical distance is longer and social interactions less frequent. Our results hold in a pay change regression. They are also robust to adding state fixed effects and firm fixed effects. Practically, our research suggests that social pressure contributes meaningfully to every rising CEO pay. This understanding enables policy makers, large institutional investors, and boards to use alternative incentives (other than increasing pay and regulations) to effectively address CEOs' need for status.
\end{abstract}

Keywords: CEO; Compensation; Wealth; Social Pressure; Elites

\section{INTRODUCTION}

ncreases in CEO compensation since the early 1990s have caused many people to question whether CEOs have too much influence on their own pay. ${ }^{1}$ What drives highly-paid CEOs to want higher pay and why the board of directors approves such demand remains far from fully understood. To shed light on this puzzle from a new perspective, we investigate the effect of social interactions and pressures from social peers on CEO compensation. In particular, we show that CEO compensation contains a component (referred to as the social premium) that is positively linked to various sources of social pressures.

As is well documented in the sociology and economics literature, happiness depends, at least in part, on the income one has relative to that of his reference group. Seidl, Traub, and Morone (2006) document the effect of relative income in experimental studies; Hagerty (2000) and McBride (2001) do so in empirical studies; and Hamermesh (1975) formally models the influence of relative wages on managerial incentives. Arthur Pigou (1920) quotes John Stuart Mill's observation that "men do not desire to be rich, but richer than other men." That is, one strives to earn a wage greater than one's peer group; the desire for higher pay is intensified when one can readily observe the display of wealth by peers (Hamermesh 1975). ${ }^{2}$

In the recent literature of finance, Bizjak, Lemmon, and Naveen (2008) show CEO pay is benchmarked against industry peers of comparable size. Faulkender and Yang (2010) and Bizjak, Lemmon, and Nguyen (2011) show that in addition to industry and size consideration, firms select peer companies that pay their CEOs more generously to justify CEO pay. Also in the recent literature, social ties are found to significantly affect board decisions such as takeovers (Renneboog and Zhao 2014). In this paper, we examine the effect of social peers on CEO pay.

\footnotetext{
${ }^{1}$ See, for example, Bertrand and Mullainathan (2001), Bebchuk and Fried (2004), and Morse, Nanda, and Seru (2011) for arguments and empirical findings of managerial entrenchment. Some of the pay increases can be explained by the increasing importance of managerial talent due to technological innovation and globalization; see, for example, Murphy and Zabojnik (2004), Oyer (2004), Gabaix and Landier (2008), Edmans, Gabaix, and Landier (2009), Kaplan and Rauh (2011), and Baranchuk, MacDonald, and Yang (2011).

${ }^{2}$ The resulting continual demand for higher pay is known as the "hedonic treadmill" hypothesis (Firebaugh and Tach 2005).
} 
A CEO encounters social pressures from various social interactions with peers, and thus, we examine the impact of social pressures on CEO pay from a rather exhaustive list of sources. Social pressures may come from influential people in the local area with whom a CEO routinely interacts. Thus, we investigate social pressure from local CEOs, local people on Forbes 400 list, local social elites, and top wealth holders in the state as defined by the IRS. Social pressures may also come from broader social circles beyond local contact, so we examine the influence on CEO pay of industry peers. Moreover, we look at the means by which rich people display wealth: luxury home values in the local area (MSA), and CEO home values for a subsample of 523 CEOs with available data in 2004. The results show that each of these sources of social pressures contributes independently to the elevation of CEO pay.

We primarily define a CEO's social peers as other CEOs of firms whose corporate headquarters are located within 60 miles (100-kilometer) of the headquarters of the CEO's firm. We use the locations of corporate headquarters to define social circles for several reasons. First, business-related social activities of CEOs often occur in the communities where corporate headquarters are located. Second, the median distance between the corporate headquarters of S\&P 500 firms and the main residences of their CEOs is 13.6 miles (Liu and Yermack 2007), and hence most non business-related social activities of CEOs also takes place near corporate headquarters. Third, the location of corporate headquarters is determined by factors largely exogenous to current CEO compensation, such as the origin of the founding family, infrastructure, local taxes and costs, availability of human capital, and the proximity to raw materials, suppliers, and customers. Thus, using locations of corporate headquarters helps mitigate the endogeneity problem that CEOs and their pay determine the choice of social circles via the selection/relocation of corporate headquarters. Finally, the choice of the 60-mile distance is based on many studies in sociology, economics, and finance. ${ }^{3}$

We use the size of a social circle instead of the lagged average pay in the circle as the main proxy for social pressures because most firms treat their CEOs as above average. For example, Bizjak, Lemmon, and Nguyen (2011) show that almost all firms benchmark their CEO pay against the median or higher percentiles of CEO pay of their compensation peer companies, regardless of their size relative to the size of their peers. Or perhaps, some firms use generous pay packages as a signal mechanism to convince the capital market that their CEOs are talented and thus these firms are more valuable (Hayes and Schaefer 2009).

To show that social circles affect CEO pay through social comparisons and social pressures and this effect is not due to other known determinants of CEO pay, we incorporate a host of factors previously shown to affect CEO compensation: firm characteristics, performance (in the past, current, and future years), governance structures, influence of industry peers, industry fixed effects, year fixed effects, and various location-specific variables.

Our study, which focuses on the S\&P 1500 companies, yields the following findings. First, CEO compensation contains a social premium. Using the value of ex-ante total annual pay, we find that the average pay for a CEO increases by $\$ 550,000$ as the number of local CEOs increases from 15 to 79 (moving from the $25^{\text {th }}$ to $75^{\text {th }}$ percentile of the sample), all else equal. We further show that social premiums exist for interacting with wealthy people in the local social circles to whom CEOs compare in terms of socio-economic status. Social premiums remain after controlling for location-specific factors: state fixed effects, stock returns of local firms, non-linear effect of the cost of living index for professionals, and the price index for luxury homes (the $99^{\text {th }}$ percentile of home values in the MSA). Moreover, the social premium result holds if we exclude the largest social circles or add firm fixed effects, and when we link the change in social circle size to the change in CEO pay.

We then examine how the strength of social pressures varies with distance. Prior literature (Watts 2004; Kleinberg 2001; Mok, Carrasco, and Wellman 2009) shows that the frequency of face-to-face interactions decreases with geographic distance. As a result, the strength of social pressures and their influence on CEO pay should

\footnotetext{
${ }^{3}$ Watts (2004) shows the importance of geography in people's social network. Kleinberg (2001) suggests defining a set of geographic groups by "centering" groups of various geographic radii at each person in the network. Urry (2007) documents that an average American traveled about 30 miles per day in the 2000s. Moreover, the 60-mile distance is practical for attending social events, which occur fairly frequently but not every day. It has also been used in numerous studies in economics and finance such as Kedia and Rajgopal (2009), Malloy (2005), and Coval and Moskowitz (2001). Alternative distances were also used in the literature: Ivkovic and Weisbenner (2007) use 50 miles in defining whether investors are in the neighborhood of the firms in which they invest.
} 
decrease with distance. We test the effect of geographic distance on social premiums and find that the strongest effect exists in social circles within 30 miles of the headquarters of the CEO's firm; the effect is weakened by $45 \%$ in social circles of 30 to 60 miles but remains statistically significant at better than $1 \%$. Social circles beyond 60 miles do not affect CEO pay. This evidence helps address the potential concern that local social peers are picking up the effect of unspecified local variables (e.g. culture, access to local amenities and infrastructure, etc.) because those local factors do not change as dramatically as social interactions when the distance increases from 30 to 60 miles.

Next, we differentiate social pressures from a (potential) local labor market for CEOs. First, it is difficult to argue that the labor market for CEOs of the largest US companies is localized even though competition for directors and rank-and-file workers was shown in the local area (Knyazeva, Knyazeva, and Masulis 2014; Kedia and Rajgopal 2009). For the sake of argument, suppose the labor market for CEOs is localized. In an area with more large firms (i.e., more peer CEOs), both the demand and supply of talented CEOs are stronger. This may lead to a higher or lower average pay for local CEOs. In one analysis, we control for the lagged average CEO pay in the local area (self-excluded) and still find that the number of local CEOs and the area's top pay significantly affect the level of CEO pay. In a regression including both the number of local CEOs and the lagged average CEO pay in the local area, only the former survives. Actually, the effect of lagged average CEO pay in the local area disappears when state fixed effects are added, absent the number of local CEOs. It appears that the display of wealth by top earners in the social circle, rather than the average peer pay, presses CEOs to feel strongly about income and wealth.

One may argue that firms in the same industry tend to locate their headquarters in close proximity, and perhaps, the number of local peer companies simply reflects competition for managerial talent from industry peers. In all regressions (except for the one with firm fixed effects), we include industry fixed effects. To further address this concern, in one additional analysis, we allow for pay comparison with industry peers and find that the social premium in CEO pay continues to hold.

One may argue that the number of nearby CEOs could be reflecting a CEO's social connections and correspondingly, his ability to increase shareholder value (Engelberg, Gao, and Parsons 2013). ${ }^{4}$ We believe that higher managerial ability should be converted into stronger performance at some points of a CEO's tenure. Thus, we explicitly control for past, current, and future stock and accounting performance (up to three years in the future) in the analysis and find that the social premium holds.

Overall, we look into various dimensions of a CEO's social life and examine the influence of different groups of social peers on CEO compensation. A CEO may often interact with other CEOs, social elites, and wealthy people in the local proximity. From time to time, they may also socialize with industry peers. Social pressures could provide an explanation as to why highly paid CEOs believe they deserve even better pay because their peers, which they may consider as equal or inferior, are well paid. Social pressures, rather than pure greed, could incentivize CEOs to obtain higher pay. ${ }^{5}$ This understanding can lead policy makers and institutions to advocate for alternative incentives (other than increasing pay and regulations to contain pay) to address CEOs' need for status and its effect on their pay.

\section{DATA, PRELIMINARY ANALYSIS, AND EMPIRICAL STRATEGY}

In this section, we describe the data, conduct a preliminary analysis, and state the main empirical strategy for the multivariate analysis. Our sample contains the Standard and Poor's (S\&P) 1500 companies between 1994 and 2005 with performance data through 2009. The S\&P 1500 companies are comprised of the S\&P 500, S\&P Mid Cap 400, and S\&P Small Cap 600 companies. We use the historical S\&P 1500 indices to identify sample firms. ${ }^{6}$

\footnotetext{
${ }^{4}$ Hwang and Kim (2009) and Nguyen (2102) show that a board that is socially connected to the CEO is less likely to be an effective monitor. Kuhnen and Niessen (2012) show the influence of public opinion on the board's decision to compensation the CEO.

${ }_{6}^{5}$ Appendix A examines the effect of corporate governance.

${ }^{6}$ Our results are robust to using the S\&P 500, S\&P Mid Cap 400 and S\&P Small Cap 600 index components as defined by Standard \& Poor's in 2005.
} 


\section{Variable Descriptions}

The pay determination model includes the following pay determinants identified by existing research: (1) stock and accounting performance; (2) complexity and risks of managerial tasks (size, market-to-book, growth, and risks); (3) corporate governance (whether the CEO serves as the chairman of the board, CEO tenure, the percentage ownership of blockholders, institutions and insiders; the number of directors, the percentage of inside directors, and the GIM index); (4) local economic environment (returns of local stocks in excess of market returns and the cost of living index at the Metropolitan Statistical Area, MSA, level); and (5) social variables (the number of S\&P 1500 CEOs, Forbes 400 people, and social elites in the local area; the luxury home value in the MSA; the number of the CEO's prominent alumni; and the number of non-profit organization boards on which the CEO serves). We refer to the variables in groups (1) and (2) as the economic variables.

We use the size of a social circle as the main proxy for social pressures. Bizjak, Lemmon, and Nguyen (2011) show that all but two firms in their sample benchmark their CEO pay against the median or higher percentiles of CEO pay of their compensation peer companies, regardless of their size relative to the size of their peers. It seems that firms either believe their CEOs to be more talented than the average peer CEO, or they simply try to convince investors that their CEOs have a superb ability by awarding more generous CEO pay packages (Hayes and Schaefer 2009). We note that using the $90^{\text {th }}$ percentiles of CEO pay rather than the number of CEOs in the social circles to proxy for social pressure yields similar results (untabulated results).

An alternative measure for social pressure is the average compensation of other CEOs in the same social circle in the previous year. The implicit assumption for using this measure is that a CEO considers himself just as good as his ordinary peers in the same circle. We examine the effect of this alternative measure separately, and in a horse-race specification that include in the same regression both the size of the social circle and the lagged average CEO pay level of the circle.

Compensation variables are from the ExecuComp database: the ex-ante total pay (TDC1) includes salary, bonuses, other annual compensation, total value of stock options and restricted stock granted during the year, longterm incentive payout, and other compensation. Share price information is from the University of Chicago's Center for Research in Security Prices (CRSP). Company financial and accounting information is from the Standard and Poor's Compustat database. Historical locations of corporate headquarters are found using historical zip codes, provided by Compact Disclosure. These zip codes are then linked to the latitudes and longitudes at www.census.gov/geo/maps-data/gazetteer.html. The ACCRA cost of living indexes of each year are provided by the Council for Community and Economic Research (www.coli.com). The sources for governance and director variables include the Investor Responsibility Research Center (IRRC), Corporate Proxy, and Compact Disclosure.

Individuals included in the Forbes 400 list in each year of our sample period are assigned latitude and longitude positions based on the state and city information provided by Forbes; then each Forbes 400 individual is assigned to the 60 -mile radius of the corporate headquarters. IRS top wealth holder data are provided by the IRS in 1998 (http://www.irs.gov/pub/irs-soi/98pwart.pdf). Home locations of social elites are found via zip codes of all people listed in the Social Register, 2004 Edition. Luxury home values by MSA are provided by a private source that also provided the data to Business Week.

\section{Preliminary Analysis}

Table 1 provides descriptive statistics for variables used in the analysis. Panel A summarizes compensation variables. The average and median of total annual compensation for the sample CEOs are \$5.009 million and \$2.649 million, respectively. Panel B lists nine variables regarding CEO social circles. Column 1 describes the primary measure of the social circle size: the number of S\&P 1500 firms headquartered with 60 miles of the firm's headquarters (local CEOs). The count includes the firm itself. The average number of local CEOs is 59.9, the median is 45 , and the $25^{\text {th }}$ and $75^{\text {th }}$ percentiles are 15 and 79 , respectively. The largest social circle is in the MSA of New York-Northern New Jersey-Long Island (NY-NJ-PA), which contains 157 of the S\&P 1500 firms. There are 262 CEOs who have no peer CEOs within the 60-mile radius (for example, both Bismarck, ND and Tupelo, MS have only one of the S\&P 1500 firms). Column 2 shows the year-to-year changes of the number of local CEOs due 
to adjustments of the S\&P index components (including the addition of the Small Cap 600 firms to the S\&P index in October, 2004, as well as addition and deletion of firms due to changes in market capitalization and liquidity, mergers, acquisitions, bankruptcies, and privatizations) and relocations of corporate headquarters.

The sample in Panel A as well as the sample in Panels C and D is comprised of S\&P 1500 firms between 1994 and 2005 with all of the variables needed for the regression analysis in Table 2 . The sample in Panel B is further restricted by the availability of social variables. Unless otherwise stated, samples throughout the paper exclude the year in which the firm's headquarters was moved over 30 miles (because the number of local CEOs is indeterminate in the relocation year). Variable definitions are given in the Appendix Table. Throughout the paper, all compensation variables and social variables are winsorized at the $1^{\text {st }}$ and $99^{\text {th }}$ percentiles of the sample.

Table 1. Summary statistics

Panel A: Compensation variable

\begin{tabular}{l|c}
\hline \multicolumn{1}{c|}{ Statistics } & $\begin{array}{c}\text { Total pay } \\
\text { (TDC1, thousands of dollars) }\end{array}$ \\
\hline Average & 5,009 \\
SD. & 6,681 \\
$25^{\text {th }}$ percentile & 1,319 \\
$50^{\text {th }}$ percentile & 2,649 \\
$75^{\text {th }}$ percentile & 5,615 \\
Observations & 14,529 \\
\hline
\end{tabular}

Panel B: Social variables

\begin{tabular}{|c|c|c|c|c|c|c|}
\hline 总 & 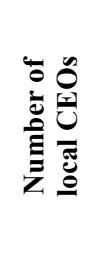 & 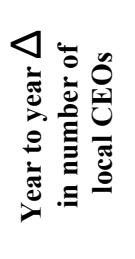 & 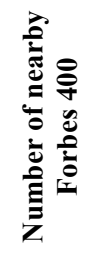 & 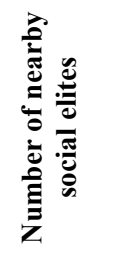 & 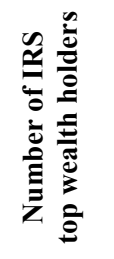 & 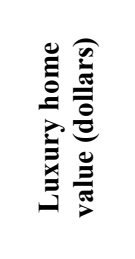 \\
\hline $\begin{array}{l}\text { Average } \\
\text { SD. } \\
25^{\text {th }} \text { percentile } \\
50^{\text {th }} \text { percentile } \\
75^{\text {th }} \text { percentile } \\
\text { Observations }\end{array}$ & $\begin{array}{c}59.9 \\
54.2 \\
15.0 \\
45.0 \\
79.0 \\
14,529\end{array}$ & $\begin{array}{c}1.2 \\
8.2 \\
-1.0 \\
0.0 \\
2.0 \\
12,166 \\
\end{array}$ & $\begin{array}{c}17.4 \\
19.4 \\
3.0 \\
9.0 \\
25.0 \\
14,529\end{array}$ & $\begin{array}{c}1,356 \\
1,993 \\
101 \\
272 \\
1,521 \\
14,529\end{array}$ & $\begin{array}{c}142.4 \\
125.4 \\
51.5 \\
85.0 \\
156.0 \\
14,464\end{array}$ & $\begin{array}{c}1,097,561 \\
689,524 \\
641,147 \\
867,064 \\
1,390,013 \\
9,593\end{array}$ \\
\hline
\end{tabular}

Panel C: Economic and local variables

\begin{tabular}{|c|c|c|c|c|c|c|c|c|c|}
\hline \multirow[b]{2}{*}{ 苞 } & \multirow[b]{2}{*}{ 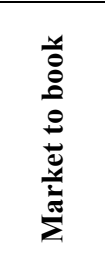 } & \multirow[b]{2}{*}{ 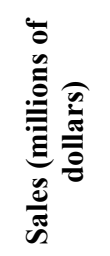 } & \multirow[b]{2}{*}{ 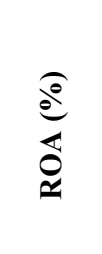 } & \multirow[b]{2}{*}{ 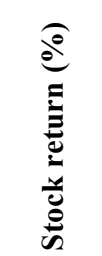 } & \multicolumn{2}{|c|}{ Firm risk $(\sigma)$} & \multicolumn{3}{|c|}{ Local factors } \\
\hline & & & & & 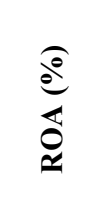 & 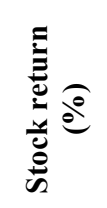 & 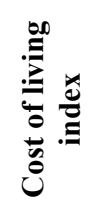 & 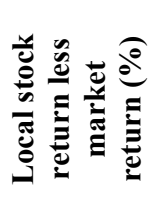 & 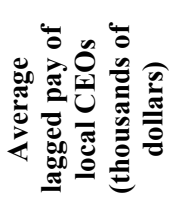 \\
\hline Average & 3.39 & 5,786 & 4.05 & 15.68 & 3.86 & 39.75 & 117.3 & 10.95 & 5,491 \\
\hline SD. & 8.95 & 15,334 & 11.38 & 49.54 & 7.21 & 19.51 & 33.9 & 26.54 & 3,278 \\
\hline $25^{\text {th }}$ percentile & 1.55 & 629 & 1.44 & -11.78 & 1.03 & 26.66 & 96.5 & -0.87 & 3,409 \\
\hline $50^{\text {th }}$ percentile & 2.24 & 1,585 & 4.28 & 10.05 & 2.18 & 35.13 & 102.8 & 6.43 & 4,892 \\
\hline $75^{\text {th }}$ percentile & 3.53 & 4,769 & 8.05 & 34.49 & 4.31 & 47.87 & 130.3 & 16.75 & 6,751 \\
\hline Observations & 14,529 & 14,529 & 14,529 & 14,529 & 14,529 & 14,529 & 14,529 & 14,529 & 14,214 \\
\hline
\end{tabular}


(Table 1 continued)

Panel D: Governance variables

\begin{tabular}{|c|c|c|c|c|c|c|c|c|}
\hline 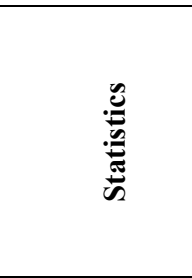 & 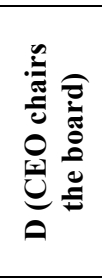 & 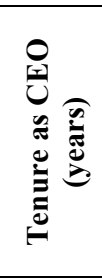 & 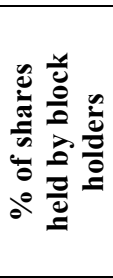 & 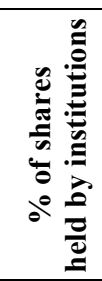 & 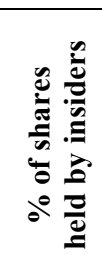 & 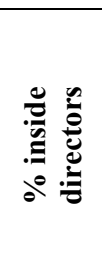 & 离 & 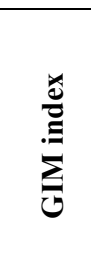 \\
\hline Average & 0.67 & 7.95 & 32.2 & 63.8 & 6.4 & 30.1 & 9.41 & 9.28 \\
\hline SD. & 0.47 & 7.59 & 22.7 & 21.7 & 11.3 & 24.9 & 3.79 & 2.69 \\
\hline $25^{\text {th }}$ percentile & 0.00 & 3.00 & 14.7 & 50.4 & 0.6 & 14.3 & 7.00 & 7.00 \\
\hline $50^{\text {th }}$ percentile & 1.00 & 6.00 & 29.2 & 66.3 & 1.8 & 22.2 & 9.00 & 9.00 \\
\hline $75^{\text {th }}$ percentile & 1.00 & 11.00 & 45.8 & 79.8 & 6.9 & 33.3 & 12.00 & 11.00 \\
\hline Observations & 14,529 & 14,529 & 14,529 & 14,529 & 14,529 & 14,529 & 14,529 & 14,529 \\
\hline
\end{tabular}

Column 3 of Panel B reports the number of Forbes 400 people who live within 60 miles of the firms' headquarters. Column 4 reports the number of social elites who live within 60 miles of the company's headquarters. Social elites include those who inherited wealth, top executives and former top executives, of whom very few are current CEOs of S\&P 1500 firms; see the 2004 Social Register published by the Social Register Association in New York. Column 5 reports the number of top wealth holders in the state of the firm's headquarters. It is provided by the IRS in 1998 (count of individuals with wealth above \$1 million). ${ }^{7}$ Column 6 reports the value of luxury homes (the $99^{\text {th }}$ percentile of home values in the CEO's MSA). ${ }^{8}$ This variable, different from the cost of living index, is directly relevant for social comparisons, especially those with people in the local area and is thus closely related to social premiums in CEO pay. A few of the six social variables are highly correlated. ${ }^{9}$ Thus in the empirical specifications, we orthogonalize different social variables to capture the incremental effect on CEO compensation of each social venue.

Panel $\mathrm{C}$ of Table 1 summarizes traditional pay determinants such as firm performance, risk, and complexity of business. It also contains economic conditions such as the cost of living index given by MSA and excess returns of local stocks, as measured by the value-weighted return (TRS1YR) of all companies headquartered within 60 miles of the firm's headquarters less the CRSP value-weighted monthly market return (VWRETD). In the regressions on social premiums, we control for these two local variables to show that social premiums in CEO compensation do not merely reflect pay adjustments for different living standards in different areas. Average lagged pay for local CEOs will be used as a proxy for the extent of competition for managerial talent in the local labor market (if it exists). Panel D describes eight corporate governance measures previously shown to affect CEO compensation (Core, Holthausen, and Larcker 1999; Bebchuk and Cohen 2005).

\section{Empirical Strategy}

The multivariate analyses examine the effect of social pressures on social premiums in CEO compensation. The baseline model has two groups of variables: the size of the social circle, a proxy for social pressures, and firm characteristics.

$\operatorname{Ln}(T D C 1)=f($ Ln(size of the social circle), market-to-book, $\sigma(R O A), \sigma($ stock return $)$, Ln(sales), ROA, lagged ROA, stock return, lagged stock return),

\footnotetext{
${ }_{8}^{7}$ Our results are similar if we use the number of top wealth holders by state in 1995 .

${ }^{8}$ In our sample, the mean and median of luxury home values in all MSAs are $\$ 1.10$ million and $\$ 0.87$ million, respectively; these values are $\$ 1.41$ million and $\$ 1.06$ million, respectively, in 2005. These values are lower than $\$ 2.3$ million, the median market value of the main residences for S\&P 500 CEOs in late 2006 (See Liu and Yermack, 2007). Considering that our sample includes CEOs of S\&P 500, Mid Cap 400, as well as Small Cap 600 firms and that the price in the housing market had increased significantly during our sample period, we believe luxury home values in the MSA could serve as a proxy for the values of luxury homes in the local area to which CEOs, social elites, and their spouses pay attention. Moreover, for a subsample of 523 CEOs (Cronqvist, Makhija, and Yonker, 2012) that we have the purchase prices of their homes, the mean and median values of CEO homes are $\$ 1.68$ million and $\$ 1.11$ million, respectively.

${ }^{9}$ Only the correlation between the number of S\&P 1500 CEOs and the number of Forbes 400 people in the local area is greater than 0.6.
} 
where size of the social circle is the number of local CEOs for the baseline specification.

This specification is in line with the economic model for executive pay (Core, Holthausen, and Larcker 1999; and Murphy 1999) in which CEOs are compensated for stock and accounting performance, for managing complex operations, and for taking risks and generating growth. We winsorize CEO compensation and the number of local CEOs at the $1^{\text {st }}$ and $99^{\text {th }}$ percentiles, then take a logarithmic transformation of each to overcome the skewness in the data. Economically, the coefficient estimate of $\operatorname{Ln}$ (number of local CEOs) measures the elasticity of CEO pay to social circle size.

We then add corporate governance variables and local economic variables, as previously described in the section, "Variable Descriptions", to this baseline model. It is also critical to filter out the portion of CEO compensation adjusted for the local living standard before attributing CEO compensation to pressures from local social peers. We include indicators for the Fama-French 49 industry classifications in all regressions. Because the sample contains panel data over 12 years, we cluster standard errors at the firm level (Petersen 2009) and add year dummy variables in all regressions. In the robustness tests, we add state fixed effects to account for the effect of time-invariant and state-specific characteristics that are omitted in the specifications.

\section{EMPIRICAL RESULTS}

In this section, the focus is on the effect of one social circle: local CEOs. We first show that the positive link between CEO pay and the number of local CEOs holds in multivariate regression analyses. The number of S\&P 1500 companies whose headquarters are located within 60 miles of the headquarters of the CEO's firm measures the size of the social circle and serves as a proxy for social pressures. Table 2 summarizes the main empirical findings: CEO compensation increases with the number of local CEOs after controlling for other pay determinants; that is, we show that the social premium exists.

There are four specifications, each of which uses the ex-ante total annual pay $\operatorname{Ln}(\mathrm{TDC} 1)$ as the dependent variable and includes an expanded set of explanatory variables. Column 1 reports the results using the number of local CEOs and a set of economic variables as explanatory variables. The coefficient estimate of $\operatorname{Ln}$ (number of local CEOs) has the predicted positive sign and is statistically significant at better than $1 \%$. Not surprisingly, CEOs of larger firms and firms with higher risks, higher growth and better performance receive higher pay.

Column 2 adds eight corporate governance variables, seven of which are statistically significant at better than $10 \%$. CEO compensation is higher at firms in which the CEO chairs the board, institutional shareholders have higher ownership, the board is larger, and the GIM index is higher. CEO compensation is lower at firms in which block holders and insiders have higher ownership, and the CEO has been at the post longer. These findings are consistent with the existing literature on executive compensation such as Core, Holthausen, and Larcker (1999), and Hartzell and Starks (2003).

Two local variables added in Column 3 measure local economic conditions that may affect the level of CEO compensation: the cost of living index in the MSA and the excess returns of local stocks. The coefficient of the former is positive and significant at the $5 \%$ level. This indicates that CEO compensation is adjusted for local economic conditions. ${ }^{10}$ More importantly, $\mathrm{Ln}$ (number of local CEOs) is significant at better than $1 \%$, suggesting the social premium goes beyond compensating CEOs for different living standards in different geographic areas. Economically, the average social premium for a CEO in a social circle with 79 CEOs (the $75^{\text {th }}$ percentile of social circles) is $\$ 0.555$ million higher than the average social premium for a CEO in a social circle with $15 \mathrm{CEOs}$ (the $25^{\text {th }}$ percentile of social circles). ${ }^{11}$ This pay increase corresponds to $11 \%$ and $21 \%$, respectively, of the mean and median of the total annual pay for our sample CEOs. ${ }^{12}$

\footnotetext{
${ }^{10}$ The results are robust to using housing price indices by MSA, provided by the Office of Federal Housing Enterprise Oversight (OFHEO).

${ }^{11}$ The average pay for S\&P 1500 CEOs in a social circle with 15 CEOs is $\$ 3.908$ million. The predicted average pay for S\&P 1500 CEOs in a social circle with 79 CEOs is calculated as follows: $\operatorname{Ln}($ pay(79)) $-\operatorname{Ln}($ pay(15)) $=0.0799 *(\operatorname{Ln}(79)-\operatorname{Ln}(15))$, where the value of 0.0799 is obtained from Column 3 of Table 2. Thus, pay $(79)=3.908 * \operatorname{Exp}(0.0799 * \operatorname{Ln}(79 / 15))=\$ 4.463$ million. This is higher than the average compensation for CEOs in circles with 15 CEOs by $4.463-3.908=\$ 0.555$ million, all else equal.

${ }_{12}$ The social premium also exists if we use the number of local CEOs in the previous year as the main explanatory variable. Our interpretation is as follows. A CEO learns from either public sources or face-to-face interactions with other local CEOs about what level of pay is needed to maintain or improve social ranking. In those cases, the desired pay packages are implemented the following year. In many other cases, the CEO could form the pay
} 
Column 4 adds indicators for firms in the S\&P 500 index and firms in the S\&P Mid Cap 400 index as well as their interactions with $\mathrm{Ln}$ (number of local CEOs). This specification is designed to investigate whether CEOs of large firms are under greater social pressures. We find that social premiums appear to be higher for CEOs at the S\&P 500 firms, but the difference is not statistically significant. ${ }^{13}$

The sample is comprised of S\&P 1500 firms between 1994 and 2005. The dependent variable is $\operatorname{Ln}(T D C 1)$ (TDC1 is the total annual pay in ExecuComp, expressed in 2005 dollars). $D(S \& P 500)$ is an indicator variable that is set to 1 if the firm is a member of the S\&P 500 index; 0 otherwise. D(Mid Cap) is an indicator variable that is set to 1 if the firm is a member of the S\&P Mid Cap index; 0 otherwise. All other variables are defined in the Appendix Table. Standard errors are clustered at the firm level when computing significance; $t$-statistics are given in parentheses below each reported coefficient; ${ }^{* *}, * *$, and ${ }^{*}$ denote $p$-value $\leq 0.01,0.05$ and 0.10 , respectively.

Table 2. Social premiums in CEO compensation: local CEO peers

\begin{tabular}{|c|c|c|c|c|}
\hline \multirow{2}{*}{ Dependent variable } & \multicolumn{4}{|c|}{$\operatorname{Ln}(\mathrm{TDC} 1)$} \\
\hline & (1) & $(2)$ & (3) & (4) \\
\hline \multicolumn{5}{|l|}{ Social variables } \\
\hline Ln(number of local CEOs) & $\begin{array}{l}0.0912 * * * \\
(9.20)\end{array}$ & $\begin{array}{l}0.0913 * * * \\
(9.20)\end{array}$ & $\begin{array}{l}0.0799 * * * \\
(7.39)\end{array}$ & $\begin{array}{l}0.0625 * * * \\
(4.28)\end{array}$ \\
\hline $\operatorname{Ln}($ number of local CEOs $) * \mathrm{D}(\mathrm{S} \& \mathrm{P} 500)$ & & & & $\begin{array}{l}0.0249 \\
(1.16)\end{array}$ \\
\hline Ln(number of local CEOs) $*$ D(Mid Cap) & & & & $\begin{array}{l}0.0114 \\
(0.52)\end{array}$ \\
\hline $\mathrm{D}(\mathrm{S} \& \mathrm{P} 500)$ & & & & $\begin{array}{l}0.3469^{* * * *} \\
(4.21)\end{array}$ \\
\hline D(Mid Cap) & & & & $\begin{array}{l}0.1659 * * \\
(2.08)\end{array}$ \\
\hline \multicolumn{5}{|l|}{ Economic variables } \\
\hline Market-to-book & $\begin{array}{l}0.0039 * \\
(1.80) \\
\end{array}$ & $\begin{array}{l}0.0033^{*} \\
(1.74) \\
\end{array}$ & $\begin{array}{l}0.0033^{*} \\
(1.76) \\
\end{array}$ & $\begin{array}{l}0.0023^{*} \\
(1.65) \\
\end{array}$ \\
\hline Firm risk (ROA) & $\begin{array}{l}0.0072^{* *} \\
(2.30)\end{array}$ & $\begin{array}{l}0.0078^{* *} \\
(2.33)\end{array}$ & $\begin{array}{l}0.0077^{* *} \\
(2.32)\end{array}$ & $\begin{array}{l}0.0052 * \\
(1.84)\end{array}$ \\
\hline Firm risk (stock returns) & $\begin{array}{l}0.0190 * * * \\
(5.06)\end{array}$ & $\begin{array}{l}0.0195 * * * \\
(5.40)\end{array}$ & $\begin{array}{l}0.0195 * * * \\
(5.44)\end{array}$ & $\begin{array}{l}0.0200 * * * \\
(5.61)\end{array}$ \\
\hline Ln(sales) & $\begin{array}{l}0.4512 * * * \\
(46.56)\end{array}$ & $\begin{array}{l}0.4145^{* * *} \\
(38.52)\end{array}$ & $\begin{array}{l}0.4143 * * * \\
(38.53)\end{array}$ & $\begin{array}{l}0.3246 * * * \\
(22.46)\end{array}$ \\
\hline ROA & $\begin{array}{l}0.0007 \\
(0.66) \\
\end{array}$ & $\begin{array}{l}0.0009 \\
(0.75)\end{array}$ & $\begin{array}{l}0.0009 \\
(0.76) \\
\end{array}$ & $\begin{array}{l}0.0004 \\
(0.37) \\
\end{array}$ \\
\hline Prior year ROA & $\begin{array}{l}0.0017 \\
(1.48) \\
\end{array}$ & $\begin{array}{l}0.0024 * * \\
(2.03)\end{array}$ & $\begin{array}{l}0.0024^{* *} \\
(2.03)\end{array}$ & $\begin{array}{l}0.0019 * * * \\
(1.74)\end{array}$ \\
\hline Stock return & $\begin{array}{l}0.0018 * * * \\
(10.56)\end{array}$ & $\begin{array}{l}0.0016^{* * *} \\
(9.20)\end{array}$ & $\begin{array}{l}0.0016^{* * *} \\
(8.95)\end{array}$ & $\begin{array}{l}0.0017 * * * \\
(9.88)\end{array}$ \\
\hline Prior year stock return & $\begin{array}{l}0.0017 * * * \\
(11.15)\end{array}$ & $\begin{array}{l}0.0016^{* * *} \\
(10.34)\end{array}$ & $\begin{array}{l}0.0016^{* * *} \\
(10.22)\end{array}$ & $\begin{array}{l}0.0017 * * * \\
(11.38)\end{array}$ \\
\hline
\end{tabular}

expectation early on through either communicating directly with local peer CEOs or shared compensation consulting firms. In those cases, CEOs can influence their own pay packages in the contemporaneous year.

${ }^{13}$ We also rerun the regression of CEO pay on the number of local CEOs using three alternative pay measures: salary, salary and bonuses, and the ex-post total pay (TDC2, which is same as TDC1 except we replace the value of options granted with the value of options exercised during the year). The social premium exists for all three alternative measures of CEO compensation and is stronger for equity-based pay (available upon request). 
(Table 2 continued)

\begin{tabular}{|c|c|c|c|c|}
\hline \multirow{2}{*}{ Dependent variable } & \multicolumn{4}{|c|}{ Ln(TDC1) } \\
\hline & (1) & (2) & (3) & (4) \\
\hline \multicolumn{5}{|l|}{ Governance variables } \\
\hline $\mathrm{D}(\mathrm{CEO}$ chairs the board $)$ & & $\begin{array}{l}0.1378^{* * *} \\
(5.76)\end{array}$ & $\begin{array}{l}0.1373 * * * \\
(5.75)\end{array}$ & $\begin{array}{l}0.1299 * * * \\
(5.51)\end{array}$ \\
\hline Tenure as CEO & & $\begin{array}{l}-0.0036^{*} \\
(-1.83)\end{array}$ & $\begin{array}{l}-0.0037^{*} \\
(-1.89)\end{array}$ & $\begin{array}{l}-0.0036^{*} \\
(-1.89)\end{array}$ \\
\hline$\%$ of shares held by blockholders & & $\begin{array}{l}-0.0022 * * * \\
(-3.68)\end{array}$ & $\begin{array}{l}-0.0023 * * * \\
(-3.73) \\
\end{array}$ & $\begin{array}{l}-0.0018 * * * \\
(-3.15)\end{array}$ \\
\hline$\%$ of shares held by institutions & & $\begin{array}{l}0.0056^{* * *} \\
(8.57) \\
\end{array}$ & $\begin{array}{l}0.0056^{* * *} \\
(8.59) \\
\end{array}$ & $\begin{array}{l}0.0052 * * * \\
(8.28) \\
\end{array}$ \\
\hline$\%$ of shares held by insiders & & $\begin{array}{l}-0.0045 * * * \\
(-4.02)\end{array}$ & $\begin{array}{l}-0.0045 * * * \\
(-4.02)\end{array}$ & $\begin{array}{l}-0.0040^{* * *} \\
(-3.70)\end{array}$ \\
\hline$\%$ inside directors & & $\begin{array}{l}0.0000 \\
(0.00)\end{array}$ & $\begin{array}{l}0.0000 \\
(-0.05) \\
\end{array}$ & $\begin{array}{l}-0.0001 \\
(-0.33)\end{array}$ \\
\hline Number of directors & & $0.0081 * *$ & $0.0080 * *$ & 0.0057 \\
\hline GIM index & & $\begin{array}{l}0.0080^{*} \\
(1.72)\end{array}$ & $\begin{array}{l}0.0085^{*} \\
(1.83)\end{array}$ & $\begin{array}{l}0.0049 \\
(1.09)\end{array}$ \\
\hline \multicolumn{5}{|l|}{ Local variables } \\
\hline Cost of living index & & & $\begin{array}{l}0.0007 * * \\
(2.06)\end{array}$ & $\begin{array}{l}0.0007 * * \\
(1.97)\end{array}$ \\
\hline Local stock return - market return & & & $\begin{array}{l}0.0002 \\
(0.65)\end{array}$ & $\begin{array}{l}0.0002 \\
(0.59)\end{array}$ \\
\hline Intercept & $\begin{array}{l}3.7595 * * * \\
(24.73) \\
\end{array}$ & $\begin{array}{l}3.6123 * * * \\
(21.92) \\
\end{array}$ & $\begin{array}{l}3.5614 * * * \\
(21.13)\end{array}$ & $\begin{array}{l}4.1525^{* * *} \\
(22.31)\end{array}$ \\
\hline Year fixed effects & Yes & Yes & Yes & Yes \\
\hline Fama-French 49 industry fixed effects & Yes & Yes & Yes & Yes \\
\hline Adjusted $R$-squared & 0.4747 & 0.4981 & 0.4983 & 0.5104 \\
\hline Observations & 15,703 & 14,529 & 14,529 & 14,529 \\
\hline
\end{tabular}

Next, we examine how geographic distance between CEOs and their social peers affects the frequency of social interactions and the intensity of social pressures. We expect the strength of social pressures to decline as the geographic distance exceeds that for a practical day trip. According to Urry (2007), the average distance of daily travels for Americans is about 30 miles. Therefore, we count respectively the number of peer CEOs in the 30 mile, 30-60 mile, and 60-120 mile radius. The results presented in Table 3 show that the impact of social pressures on CEO compensation is the highest for social circles within 30 miles, is much weaker (reduced by $45 \%$ ) for social circles between 30 and 60 miles, and disappears completely beyond 60 miles. These results are consistent with the premise that CEOs regularly attend social events within a practical distance and thus are under greater influences from peers in those close circles. The decreasing magnitude of social premiums over distance helps us further address the potential issue of omitted local variables such as weather; culture; proximity to suppliers, customers, and prestigious universities; and access to the airport, seaport, and major highways, because those local factors do not change as dramatically when the distance increases from 30 to 60 miles.

The sample is comprised of S\&P 1500 firms between 1994 and 2005. The dependent variable is $\operatorname{Ln}(T D C 1)$ (total annual pay in ExecuComp, expressed in 2005 dollars). The number of nearby CEOs is the number of S\&P 1500 CEOs within 30 miles (self-exclusive), 30-60 miles, and 60-120 miles of the headquarters location of the firm, respectively. All other variables are defined in the Appendix Table. Standard errors are clustered at the firm level when computing significance; $t$-statistics are given in parentheses below each reported coefficient. ***,**, and * denote $p$-values $\leq 0.01,0.05$ and 0.10 , respectively. 
Table 3. Geographic distance of local CEO peers

\begin{tabular}{|c|c|c|c|}
\hline \multirow[b]{2}{*}{ Sample Description } & \multicolumn{3}{|c|}{ Geographic distance of peer CEOs to the firm's headquarters } \\
\hline & $\begin{array}{c}\text { Within } 30 \text { miles } \\
\text { (1) }\end{array}$ & $\begin{array}{c}\text { In 30-60 miles } \\
(2)\end{array}$ & $\begin{array}{c}\text { In 60-120 miles } \\
(3)\end{array}$ \\
\hline \multicolumn{4}{|l|}{ Social variable } \\
\hline $\operatorname{Ln}(1+$ number of nearby CEOs $)$ & $\begin{array}{l}0.0795 * * * \\
(7.89)\end{array}$ & $\begin{array}{l}0.0437 * * * \\
(4.60)\end{array}$ & $\begin{array}{l}-0.0001 \\
(-0.01) \\
\end{array}$ \\
\hline Economic variables (see Table 2) & Yes & Yes & Yes \\
\hline Governance variables (see Table 2) & Yes & Yes & Yes \\
\hline Local variables (See Table 2) & Yes & Yes & Yes \\
\hline Intercept & Yes & Yes & Yes \\
\hline Year fixed effects & Yes & Yes & Yes \\
\hline Fama-French 49 industry fixed effects & Yes & Yes & Yes \\
\hline Adjusted $R$-squared & 0.4994 & 0.4953 & 0.4931 \\
\hline Observations & 14,529 & 14,529 & 14,529 \\
\hline
\end{tabular}

The sample is comprised of S\&P 1500 firms between 1994 and 2005. The dependent variable is $\operatorname{Ln}(T D C 1)$ (total annual pay in ExecuComp, expressed in 2005 dollars). Ln(number of local CEOs) is the number of S\&P 1500 firms headquartered within 60 miles of the headquarter location of the CEO's firm. Ln(number of CEO peers in the $M S A$ ) is the number of S\&P1500 firms headquartered in the Metropolitan Statistical Area (MSA) of the headquarter location of the CEO's firm. Economic and governance variables are the same as those in Table 2. All other variables are defined in the Appendix Table. Alternative economic variables are the same as the economic variables included in Table 2 except that ROA and prior year ROA are replaced by the industry-adjusted values of the corresponding variables. Industry-adjusted ROA is firm ROA minus the median value of ROA for the firm's Fama-French 49 industry classifications. Standard errors are clustered at the firm level when computing significance; $t$-statistics are given in parentheses below each reported coefficient. $* * *, * *$, and $*$ denote $p$-values $\leq 0.01,0.05$ and 0.10 , respectively. 
Table 4. Robustness tests on social premiums

\begin{tabular}{|c|c|c|c|c|c|c|}
\hline Sample description & 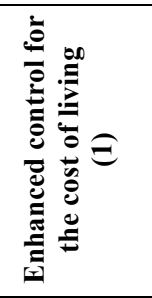 & 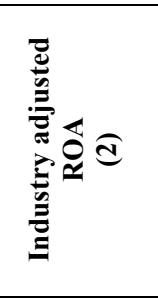 & 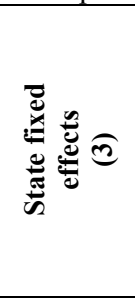 & 至 & 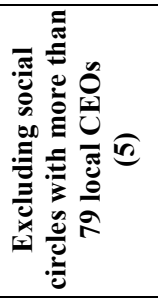 & 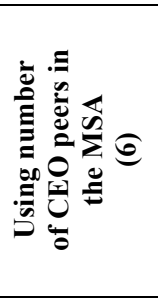 \\
\hline \multicolumn{7}{|l|}{ Social variables } \\
\hline Ln(number of local CEOs) & $\begin{array}{l}0.0777 * * * \\
(6.70)\end{array}$ & $\begin{array}{l}0.0800 * * * \\
(7.40)\end{array}$ & $\begin{array}{l}0.0691 \\
(4.85)\end{array}$ & $\begin{array}{l}0.0576^{* * *} \\
(1.96)\end{array}$ & $\begin{array}{l}0.0722 * * * \\
(5.52)\end{array}$ & \\
\hline $\operatorname{Ln}($ number of CEO peers in the MSA) & & & & & & $\begin{array}{c}0.0537 * * * \\
(5.53) \\
\end{array}$ \\
\hline $\begin{array}{l}\text { Economic variables (see Table 2) } \\
\text { Alternative economic variables } \\
\text { Governance variables (see Table 2) }\end{array}$ & $\begin{array}{l}\text { Yes } \\
\text { No } \\
\text { Yes }\end{array}$ & $\begin{array}{l}\text { No } \\
\text { Yes } \\
\text { Yes }\end{array}$ & $\begin{array}{l}\text { Yes } \\
\text { No } \\
\text { Yes }\end{array}$ & $\begin{array}{l}\text { Yes } \\
\text { No } \\
\text { Yes }\end{array}$ & $\begin{array}{l}\text { Yes } \\
\text { No } \\
\text { Yes }\end{array}$ & $\begin{array}{l}\text { Yes } \\
\text { No } \\
\text { Yes }\end{array}$ \\
\hline \multicolumn{7}{|l|}{ Local variables } \\
\hline Cost of living index & $\begin{array}{l}0.0021 \\
(0.95)\end{array}$ & $\begin{array}{l}0.0007 * * * \\
(2.04)\end{array}$ & $\begin{array}{l}0.0002 \\
(0.49)\end{array}$ & $\begin{array}{l}0.0005 \\
(1.53)\end{array}$ & $\begin{array}{l}0.0013 \\
(1.47)\end{array}$ & $\begin{array}{l}0.0014 * * * \\
(4.05)\end{array}$ \\
\hline Square of the cost of living index & $\begin{array}{l}-0.0000 \\
(-0.64) \\
\end{array}$ & & & & & \\
\hline Local stock return - market return & $\begin{array}{l}0.0002 \\
(0.65) \\
\end{array}$ & $\begin{array}{l}0.0002 \\
(0.67) \\
\end{array}$ & $\begin{array}{l}-0.0001 \\
(-0.44) \\
\end{array}$ & $\begin{array}{l}0.0010 \\
(1.02)\end{array}$ & $\begin{array}{l}-0.0002 \\
(-0.78) \\
\end{array}$ & $\begin{array}{l}0.0003 \\
(1.10)\end{array}$ \\
\hline Intercept & $\begin{array}{l}3.4697 * * * \\
(15.35)\end{array}$ & $\begin{array}{l}3.5747 * * * \\
(21.32)\end{array}$ & $\begin{array}{l}3.7055 \\
(23.41) \\
\end{array}$ & $\begin{array}{l}5.9682 * * * \\
(12.81)\end{array}$ & $\begin{array}{l}3.4493 * * * \\
(17.38)\end{array}$ & $\begin{array}{l}3.5893 * * * \\
(20.52)\end{array}$ \\
\hline Year fixed effects & Yes & Yes & Yes & Yes & Yes & Yes \\
\hline Fama-French 49 industry fixed effects & Yes & Yes & Yes & No & Yes & Yes \\
\hline Firm fixed effects & No & No & No & Yes & No & No \\
\hline State fixed effects & No & No & Yes & No & No & No \\
\hline $\begin{array}{l}\text { Adjusted } R \text {-squared } \\
\text { Observations }\end{array}$ & $\begin{array}{l}0.4984 \\
14,529\end{array}$ & $\begin{array}{l}0.4982 \\
14,529\end{array}$ & $\begin{array}{l}0.5083 \\
14,529\end{array}$ & $\begin{array}{l}0.7216 \\
14,529\end{array}$ & $\begin{array}{l}0.4912 \\
10,897\end{array}$ & $\begin{array}{l}0.4969 \\
14,529\end{array}$ \\
\hline
\end{tabular}

The social premium associated with local CEOs retains under various additional specifications; see results reported above in Table 4. First, social premiums are not merely reflecting the non-linear impact of costs of living, as reported in Column 1; and are robust to defining performance relative to the industry median; see Column 2. In addition, the social premium result survives when state fixed effects are added into the regression; see Column 3. Column 4 shows the robustness of the results after controlling for firm fixed effects, which helps to address the potential endogeneity problem due to omitted variables that are firm-specific and do not vary much over time. More important, the social premium result is not driven by the largest social circles, such as those in New York. When social circles with more than 79 local CEOs (the $75^{\text {th }}$ percentile of the sample) are excluded from the analysis, social premiums do not change; see Column 5. Column 6 reports the results using the number of S\&P 1500 CEOs in a CEO's MSA. In summary, the empirical findings reported in Tables 2-4 are consistent with the hypothesis that social pressures from nearby CEOs positively affect CEO compensation.

\section{SOCIAL PRESSURES VS. LOCAL LABOR MARKET FOR CEOS}

In the previous section, we establish the link between CEO compensation and the number of local CEOs after controlling for economic, governance, and local factors. One may question whether the number of local CEOs is actually a proxy for competition for CEOs in the local labor market (if it exists). Is the ability of CEOs higher on average in an area with more firms? Is it the high ability of local CEOs that drives high CEO pay? A related question is whether locations of corporate headquarters represent industry clustering in location choices, and CEOs compare their pay with other CEOs in the same industry which happen to be located in close proximity. We address these concerns in this section. 
First, we address the concern that the portion of CEO pay related to the number of local CEOs (social premium) may actually reflect the degree of competition for executive talent in the local area. More specifically, one may argue that with more firms (number of local CEOs) in the area, the greater the competition for managerial talent, the higher ability of CEOs in the area, and thus higher CEO pay. We use the average pay of local CEOs in the previous year as a proxy for the extent of competition in the local CEO labor market. This variable is added to the baseline specification used in Table 2 that includes economic, governance, and local variables, as well as industry fixed effects, year fixed effects, and state fixed effects (in a subset of regressions). The results are reported in Table 5. We find, individually, both the number of local CEOs and the lagged average pay of local CEOs significantly affect CEO pay; see Columns 1 and 2. However, when we include both variables in the same regression and conduct a test of horse race, the coefficient of the lagged peer pay decreases from 0.1108 to 0.0393 and its $p$-value is above 0.1 , while the coefficient of the number of local CEOs remains unchanged. The results are reported in Column 3 of Table 6. Moreover, when state fixed effects are added, lagged peer CEO pay loses its economic and statistical significance altogether, while the significance and magnitude of the number of local CEOs remain; see Column 4. These results are not consistent with local competition for CEOs talent being the main driver of a local CEO pay premium.

A related concern is that the number of local CEOs may be a proxy for CEO ability that the host of control variables does not fully capture. To differentiate the effect of social pressures on pay from that of CEO ability, we next add to the regression model firm future performance in addition to the past and current performance currently included in the baseline specification. ${ }^{14} \mathrm{~A}$ talented CEO should be able to deliver better performance at some point over his career, and thus receives higher pay. As shown in Table 6, our main result that the number of local CEOs affects the level of CEO pay does not change after controlling for ROA and stock returns over the past, the contemporaneous, and future periods of 1,2 , and 3 years.

The sample is comprised of S\&P 1500 firms between 1994 and 2005. The dependent variable is $\operatorname{Ln}(T D C 1)$ (TDC1 is the total annual pay in ExecuComp, expressed in 2005 dollars). Ln(average lagged pay of local CEOs) is the average of the ex-ante total pay (TDC1) of CEOs whose headquarters are located within 60 miles of the firm's headquarters. This pay variable is lagged by one year and the calculation leaves out the CEO of interest. All other variables are defined in the Appendix Table. Standard errors are clustered at the firm level when computing significance; $t$-statistics are given in parentheses below each reported coefficient; ${ }^{* *},{ }^{* *}$, and ${ }^{*}$ denote $p$-value $\leq$ $0.01,0.05$ and 0.10 , respectively.

Table 5. Local social pressure versus local talent as an explanation for CEO pay premiums

\begin{tabular}{|c|c|c|c|c|}
\hline \multirow{2}{*}{ Dependent variable } & \multicolumn{4}{|c|}{ Ln(TDC1) } \\
\hline & (1) & (2) & (3) & (4) \\
\hline \multicolumn{5}{|l|}{ Social variables } \\
\hline Ln(number of local CEOs) & $\begin{array}{l}0.0799 * * * \\
(7.39)\end{array}$ & & $\begin{array}{l}0.0778 * * * \\
(5.95)\end{array}$ & $\begin{array}{l}0.0746^{* * *} \\
(4.28)\end{array}$ \\
\hline Ln(average lagged pay of local CEOs) & & $\begin{array}{l}0.1108 * * * \\
(4.78)\end{array}$ & $\begin{array}{l}0.0393 \\
(1.62)\end{array}$ & $\begin{array}{l}0.0153 \\
(0.60)\end{array}$ \\
\hline Economic variables (see Table 2 ) & Yes & Yes & Yes & Yes \\
\hline Governance variables (see Table 2) & Yes & Yes & Yes & Yes \\
\hline Local variables (See Table 2) & Yes & Yes & Yes & Yes \\
\hline Intercept & Yes & Yes & Yes & Yes \\
\hline Year fixed effects & Yes & Yes & Yes & Yes \\
\hline Fama-French 49 industry fixed effects & Yes & Yes & Yes & Yes \\
\hline State fixed effects & No & No & No & Yes \\
\hline Adjusted $R$-squared & 0.4983 & 0.4909 & 0.4942 & 0.5042 \\
\hline Observations & 14,529 & 14,214 & 14,214 & 14,214 \\
\hline
\end{tabular}

\footnotetext{
${ }^{14}$ The board is assumed to have rational expectations, i.e., expected future performance is an unbiased estimate of future performance. This allows us to use future performance as a $\mathrm{CEO}$ ability measure.
} 
The sample is comprised of S\&P 1500 firms between 1994 and 2005. The dependent variable is $\operatorname{Ln}(T D C 1)$ (TDC1 is the total annual pay in ExecuComp, expressed in 2005 dollars). Future 1-year ROA is the firm's ROA next year; Future 2-year ROA is the firm's ROA averaged over the next two years; Future 3-year ROA is the firm's ROA averaged over the next three years. Future 1-year stock return is the firm's stock return next year; Future 2year stock return is the firm's stock return averaged over the next two years; Future 3-year stock return is the firm's stock return averaged over the next three years All other variables are defined in the Appendix Table. Standard errors are clustered at the firm level when computing significance; $t$-statistics are given in parentheses below each reported coefficient; ${ }^{* *},{ }^{* *}$, and $*$ denote $p$-value $\leq 0.01,0.05$ and 0.10 , respectively.

Table 6. Local social pressure versus CEOs' ability as an explanation for CEO pay premiums

\begin{tabular}{|c|c|c|c|c|}
\hline \multirow[b]{2}{*}{ Dependent variable } & \multicolumn{4}{|c|}{ Ln(TDC1) } \\
\hline & (1) & (2) & (3) & (4) \\
\hline \multicolumn{5}{|l|}{ Social variables } \\
\hline Ln(number of local CEOs) & $\begin{array}{l}0.0799 * * * \\
(7.39)\end{array}$ & $\begin{array}{l}0.0798^{* * * *} \\
(7.24)\end{array}$ & $\begin{array}{l}0.0807 * * * \\
(7.14) \\
\end{array}$ & $\begin{array}{l}0.0804 * * * \\
(6.93)\end{array}$ \\
\hline \multicolumn{5}{|l|}{ Economic variables } \\
\hline Market-to-book & $\begin{array}{l}0.0033^{*} \\
(1.76) \\
\end{array}$ & $\begin{array}{l}0.0034^{*} \\
(1.76) \\
\end{array}$ & $\begin{array}{l}0.0034^{*} \\
(1.75) \\
\end{array}$ & $\begin{array}{l}0.0033^{*} \\
(1.73) \\
\end{array}$ \\
\hline Firm risk (ROA) & $\begin{array}{l}0.0077^{* *} \\
(2.32) \\
\end{array}$ & $\begin{array}{l}0.0080 * * \\
(2.38)\end{array}$ & $\begin{array}{l}0.0083^{* *} \\
(2.39)\end{array}$ & $\begin{array}{l}0.0081 * * \\
(2.28)\end{array}$ \\
\hline Firm risk (stock returns) & $\begin{array}{l}0.0195 * * * \\
(5.44)\end{array}$ & $\begin{array}{l}0.0188^{* * * *} \\
(5.19)\end{array}$ & $\begin{array}{l}0.0183 * * * \\
(4.94)\end{array}$ & $\begin{array}{l}0.0179 * * * \\
(4.67)\end{array}$ \\
\hline Ln(sales) & $\begin{array}{l}0.4143 * * * \\
(38.53)\end{array}$ & $\begin{array}{l}0.4151 * * * \\
(38.11)\end{array}$ & $\begin{array}{l}0.4172 * * * \\
(37.76)\end{array}$ & $\begin{array}{l}0.4183 * * * \\
(36.88)\end{array}$ \\
\hline ROA & $\begin{array}{l}0.0009 \\
(0.76)\end{array}$ & $\begin{array}{l}0.0021^{* *} \\
(2.17)\end{array}$ & $\begin{array}{l}0.0026^{* *} \\
(2.43)\end{array}$ & $\begin{array}{l}0.0024 * * \\
(2.19)\end{array}$ \\
\hline Prior year ROA & $\begin{array}{l}0.0024 * * \\
(2.03)\end{array}$ & $\begin{array}{l}0.0026^{* *} \\
(2.14)\end{array}$ & $\begin{array}{l}0.0028^{* *} \\
(2.21)\end{array}$ & $\begin{array}{l}0.0027 * * \\
(2.08)\end{array}$ \\
\hline Stock return & $\begin{array}{l}0.0016^{* * *} \\
(8.95)\end{array}$ & $\begin{array}{l}0.0016^{* * *} \\
(8.94)\end{array}$ & $\begin{array}{l}0.0016^{* * *} \\
(8.77)\end{array}$ & $\begin{array}{l}0.0015^{* * *} \\
(8.23)\end{array}$ \\
\hline Prior year stock return & $\begin{array}{l}0.0016^{* * *} \\
(10.22)\end{array}$ & $\begin{array}{l}0.0016^{* * * *} \\
(10.13)\end{array}$ & $\begin{array}{l}0.0016^{* * *} \\
(10.03)\end{array}$ & $\begin{array}{l}0.0016 * * * \\
(9.78)\end{array}$ \\
\hline Future 1-year ROA & & $\begin{array}{l}-0.2203 * * * \\
(-2.70)\end{array}$ & & \\
\hline Future 1-year stock return & & $\begin{array}{l}-0.0002 \\
(-1.19) \\
\end{array}$ & & \\
\hline Future 2-year ROA & & & $\begin{array}{l}-0.3587 * * * \\
(-2.95)\end{array}$ & \\
\hline Future 2-year stock return & & & $\begin{array}{l}-0.0002 \\
(-0.55)\end{array}$ & \\
\hline Future 3-year ROA & & & & $\begin{array}{l}-0.3995^{* *} \\
(-2.55)\end{array}$ \\
\hline Future 3-year stock return & & & & $\begin{array}{l}-0.0009 * * \\
-1.99\end{array}$ \\
\hline Governance variables (see Table 2) & Yes & Yes & Yes & Yes \\
\hline Local variables (see Table 2) & Yes & Yes & Yes & Yes \\
\hline Intercept & Yes & Yes & Yes & Yes \\
\hline Year fixed effects & Yes & Yes & Yes & Yes \\
\hline Fama-French 49 industry fixed effects & Yes & Yes & Yes & Yes \\
\hline Adjusted $R$-squared & 0.4983 & 0.5001 & 0.5022 & 0.5037 \\
\hline Observations & 14,529 & 14,005 & 13,264 & 12,512 \\
\hline
\end{tabular}

One may argue that the number of firms in the local area may reflect competition for managerial talent from industry peers because firms in the same industry may tend to locate their headquarters in close proximity. Industry peers may benchmark against each other in determining CEO pay. To address this concern, in all empirical 
specifications, we control for time-invariant and industry-specific characteristics using Fama-French 49 industry classifications. In addition, we directly test how the change in the number of local CEOs affects the change in CEO pay, controlling for the benchmarking effect of industry peers. We first use the empirical specification of Bizjak, Lemmon, and Naveen (2008), adding to the regression the change in the number of local CEOs and its interaction with an indicator for lagging CEO pay (pay below the industry-size median level in the prior year). Then we modify the baseline specification in Table 2 to a change-on-change regression. The results reported in Table 7 confirm that a CEO whose pay was below industry-size peers receives a higher pay raise as the indicator variable of lagging CEO pay is positive and significant. More important, a CEO who has more CEO peers in the local area receives a greater pay increase, after controlling for changes in performance. Thus, both industry peers and local CEOs affect CEO pay. These two sources of pay pressures do not interact with each other, as indicated by the insignificant loading on the interaction term. To summarize, the results reported in Tables 5-7 show that social premium remains economically and statistically significant after accounting for local labor market conditions, differential CEO abilities, and pay benchmarking against industry peers.

The sample is comprised of S\&P 1500 firms between 1994 and 2005. Total pay is TDC1 (total annual pay in ExecuComp, expressed in 2005 dollars). The number of local CEOs is the number of S\&P1500 firms headquartered within 60 miles of the firm's headquarters. Column 1 follows the specification of Bizjak, Lemmon, and Naveen (2008) (BLN) in which the dependent variable is the change in the dollar value of total pay ( $\Delta$ total pay); $D($ low comp $)$ is defined as in BLN. We first sort firms into industries by the two-digit SIC code, then within each industry, we sort firms into two groups by sales in the previous year. $D$ (low comp) is set to 1 for CEOs whose pay in the previous year was below the median pay of their industry-size peers. We add to the specification the change in the number of local CEOs and its interaction term with $\mathrm{D}$ (low comp). Net income before extraordinary items is Compustat data237. The regression in Column 2 is a modification of our empirical specification in Table 2. The dependent variable is $\Delta \mathrm{Ln}$ (total pay), and we add $\mathrm{D}$ (low comp) and its interaction term. In the regression, we use changes in social, economic, and local variables; and levels of governance variables. $\Delta$ total pay, $\Delta \operatorname{Ln}$ (total pay), $\Delta$ number of local CEOs, and $\Delta$ Ln(number of local CEOs) are all winsorized at the $1^{\text {st }}$ and $99^{\text {th }}$ percentiles of the sample. All remaining variables are defined in the Appendix Table. Standard errors are clustered at the firm level when computing significance; $t$-statistics are given in parentheses below each reported coefficient; $* * *, * *$, and * denote $p$-value $\leq 0.01,0.05$ and 0.10 , respectively. 
Table 7. Industry peers and social premiums

\begin{tabular}{|c|c|c|}
\hline Dependent variable & $\begin{array}{c}\Delta \text { total pay } \\
\text { (1) }\end{array}$ & $\begin{array}{c}\Delta \text { Ln(total pay) } \\
(2)\end{array}$ \\
\hline \multicolumn{3}{|l|}{ Social variables } \\
\hline$\Delta$ number of local CEOs & $\begin{array}{l}17.7471^{*} \\
(1.93)\end{array}$ & \\
\hline$\Delta$ number of local CEOs $* \mathrm{D}$ (low comp) & $\begin{array}{l}-16.0074 \\
(-1.48) \\
\end{array}$ & \\
\hline$\Delta \operatorname{Ln}($ number of local CEOs) & & $\begin{array}{l}0.1758^{* * * *} \\
(2.98)\end{array}$ \\
\hline$\Delta \mathrm{Ln}($ number of local CEOs) $* \mathrm{D}$ (low comp) & & $\begin{array}{l}-0.0610 \\
(-0.83)\end{array}$ \\
\hline \multicolumn{3}{|l|}{ Economic variables } \\
\hline $\mathrm{D}$ (low comp) & $\begin{array}{l}1693.6222 * * * \\
(20.64)\end{array}$ & $\begin{array}{l}0.4129 * * * \\
(28.34)\end{array}$ \\
\hline Ln(lagged sales) & $\begin{array}{l}126.9389 * * * \\
(5.51)\end{array}$ & $\begin{array}{l}0.0300^{* * * *} \\
(7.32)\end{array}$ \\
\hline$\Delta$ sales & $\begin{array}{l}0.1393 * * * \\
(4.56)\end{array}$ & \\
\hline$\Delta$ net income before extraordinary items & $\begin{array}{l}0.0479 \\
(0.69) \\
\end{array}$ & \\
\hline$\Delta$ Market value of equity & $\begin{array}{l}0.0312 * * * \\
(2.71) \\
\end{array}$ & \\
\hline$\Delta$ Market-to-book & & $\begin{array}{l}0.0001 \\
(0.15)\end{array}$ \\
\hline$\Delta$ Firm risk (ROA) & & $\begin{array}{l}-0.0011 \\
(-0.44) \\
\end{array}$ \\
\hline$\Delta$ Firm risk (stock returns) & & $\begin{array}{l}0.0014 \\
(0.34)\end{array}$ \\
\hline$\Delta \mathrm{Ln}$ (sales) & & $\begin{array}{l}0.3481 * * * \\
(10.26) \\
\end{array}$ \\
\hline$\Delta \mathrm{ROA}$ & & $\begin{array}{l}0.0023^{*} \\
(1.88)\end{array}$ \\
\hline$\Delta$ Prior year ROA & & $\begin{array}{l}0.0018^{*} \\
(1.69)\end{array}$ \\
\hline$\Delta$ Stock return & & $\begin{array}{l}0.0009^{* * * *} \\
(6.78)\end{array}$ \\
\hline$\Delta$ Prior year stock return & & $\begin{array}{l}0.0009 * * * \\
(8.38)\end{array}$ \\
\hline \multicolumn{3}{|l|}{ Governance variables } \\
\hline $\mathrm{D}(\mathrm{CEO}$ chairs the board $)$ & & $\begin{array}{l}0.0711 * * * \\
(5.85) \\
\end{array}$ \\
\hline Tenure as CEO & $\begin{array}{l}19.7151 * * * \\
(4.91)\end{array}$ & $\begin{array}{l}0.0015^{* *} \\
(2.40)\end{array}$ \\
\hline$\%$ of shares held by blockholders & & $\begin{array}{l}-0.0013 * * * \\
(-4.84) \\
\end{array}$ \\
\hline$\%$ of shares held by institutions & & $\begin{array}{l}0.0011 * * * \\
(3.98)\end{array}$ \\
\hline$\%$ of shares held by insiders & & $\begin{array}{l}-0.0009^{*} \\
(-1.80)\end{array}$ \\
\hline$\%$ inside directors & & $\begin{array}{l}0.0004 \\
(1.33) \\
\end{array}$ \\
\hline Number of directors & & $\begin{array}{l}0.0033 * \\
(1.89)\end{array}$ \\
\hline GIM index & & $\begin{array}{l}-0.0004 \\
(-0.20) \\
\end{array}$ \\
\hline
\end{tabular}


(Table 7 continued)

\begin{tabular}{|c|c|c|}
\hline Dependent variable & $\begin{array}{c}\Delta \text { total pay } \\
(1)\end{array}$ & $\begin{array}{c}\Delta \text { Ln(total pay) } \\
(2)\end{array}$ \\
\hline \multicolumn{3}{|l|}{ Local variables } \\
\hline$\Delta$ Cost of living index & & $\begin{array}{l}0.0003 \\
(1.01)\end{array}$ \\
\hline$\Delta$ Local stock return - market return & & $\begin{array}{l}-0.0002 \\
(-1.16)\end{array}$ \\
\hline Intercept & $\begin{array}{l}-1934.9 * * * \\
(-10.73)\end{array}$ & $\begin{array}{l}-0.5488^{* *} \\
(-12.03) \\
\end{array}$ \\
\hline $\begin{array}{l}\text { Adjusted } R \text {-squared } \\
\text { Observations }\end{array}$ & $\begin{array}{l}0.0468 \\
13,739 \\
\end{array}$ & $\begin{array}{l}0.1264 \\
11,700 \\
\end{array}$ \\
\hline
\end{tabular}

\section{OTHER SOURCES OF SOCIAL PRESSURES}

In this section, we present other venues of social interactions that may generate pressures for elevating CEO pay. We show that each of those social venues has its own influence on CEO pay, and yet the number of local CEOs still affects CEO pay that is beyond the influence of those other sources. In addition to CEOs of other large companies in the local area, a CEO may also socialize with other nearby prominent and wealthy people. One such social circle is the superrich people included in the list of the Forbes 400, some of which are themselves CEOs or former CEOs, who live within 60 miles of the company's headquarters. We first examine the individual effect of each of the two social circles, then orthogonalize one social circle to the other; finally, we interact the two circles by examining whether a CEO with more surrounding Forbes 400 people faces more intense the pressure from local CEOs. The results reported in Table 8 shows that the number of local Forbes 400 people affects CEO pay; see Column 2. The influence on CEO pay of local CEOs dominates that of nearby Forbes 400 people, as indicated by the insignificant loading of the residual of the number of Forbes 400 people on the number of CEOs in the local area; as shown in Column 5.

The sample is comprised of S\&P 1500 firms between 1994 and 2005 with performance data through 2008. The dependent variable is $\operatorname{Ln}(T D C 1)$ (total annual pay in ExecuComp, expressed in 2005 dollars). The number of nearby Forbes 400 is the number of people who is included on the list of Forbes 400 and live within 60 miles of the firm's headquarters. Residual of Ln(number of nearby Forbes 400) on Ln(number of local CEOs) is the error term in a regression of $\operatorname{Ln}($ number of nearby Forbes 400 ) on Ln(number of local CEOs). Residual of Ln(number of local CEOS) on Ln (number of nearby Forbes 400) is defined similarly. D(more nearby Forbes 400) is an indicator variable set to 1 if the number of nearby Forbes 400 individuals is greater than or equal to the sample median; and 0 otherwise. All remaining variables are defined in the Appendix Table. Standard errors are clustered at the firm level when computing significance; $t$-statistics are given in parentheses below each reported coefficient; ***, **, and * denote $p$-value $\leq 0.01,0.05$ and 0.10 , respectively. 
Table 8. Nearby Forbes 400 individuals and social premiums

\begin{tabular}{|c|c|c|c|c|c|}
\hline \multirow[b]{2}{*}{ Dependent variable } & \multicolumn{5}{|c|}{ Ln(TDC1) } \\
\hline & (1) & (2) & (3) & (4) & (5) \\
\hline \multicolumn{6}{|l|}{ Social variables } \\
\hline Ln(number of local CEOs) & $\begin{array}{l}0.0799 * * * \\
(7.39)\end{array}$ & & $\begin{array}{l}0.0817 * * * \\
(7.45)\end{array}$ & & $\begin{array}{l}0.0616^{* * *} \\
(3.96)\end{array}$ \\
\hline $\operatorname{Ln}($ number of nearby Forbes 400$)$ & & $\begin{array}{l}0.0734 * * * \\
(6.53)\end{array}$ & & $\begin{array}{l}0.0747 * * * \\
(6.68)\end{array}$ & \\
\hline $\begin{array}{l}\text { Residual of } \operatorname{Ln} \text { (number of nearby Forbes } 400 \text { ) } \\
\text { on } \operatorname{Ln} \text { (number of local CEOs) }\end{array}$ & & & $\begin{array}{l}0.0159 \\
(0.79)\end{array}$ & & \\
\hline $\begin{array}{l}\text { Residual of } \operatorname{Ln}(\text { number of nearby CEOs) on } \\
\operatorname{Ln}(\text { number of nearby Forbes } 400)\end{array}$ & & & & $\begin{array}{l}0.0674 * * * \\
(3.45)\end{array}$ & \\
\hline $\mathrm{D}($ more nearby Forbes 400$)$ & & & & & $\begin{array}{l}-0.1640 \\
(-1.09)\end{array}$ \\
\hline $\begin{array}{l}\mathrm{Ln}(\text { number of local CEOs) } * \\
\mathrm{D}(\text { more of nearby Forbes } 400)\end{array}$ & & & & & $\begin{array}{l}0.0515 \\
(1.38) \\
\end{array}$ \\
\hline $\begin{array}{l}\text { Economic variables (see Table 2) } \\
\text { Governance variables (see Table 2) } \\
\text { Local variables (see Table 2) }\end{array}$ & $\begin{array}{l}\text { Yes } \\
\text { Yes } \\
\text { Yes }\end{array}$ & $\begin{array}{l}\text { Yes } \\
\text { Yes } \\
\text { Yes }\end{array}$ & $\begin{array}{l}\text { Yes } \\
\text { Yes } \\
\text { Yes }\end{array}$ & $\begin{array}{l}\text { Yes } \\
\text { Yes } \\
\text { Yes }\end{array}$ & $\begin{array}{l}\text { Yes } \\
\text { Yes } \\
\text { Yes }\end{array}$ \\
\hline $\begin{array}{l}\text { Intercept } \\
\text { Year fixed effects } \\
\text { Fama-French } 49 \text { industry fixed effects }\end{array}$ & $\begin{array}{l}\text { Yes } \\
\text { Yes } \\
\text { Yes } \\
\end{array}$ & $\begin{array}{l}\text { Yes } \\
\text { Yes } \\
\text { Yes } \\
\end{array}$ & $\begin{array}{l}\text { Yes } \\
\text { Yes } \\
\text { Yes }\end{array}$ & $\begin{array}{l}\text { Yes } \\
\text { Yes } \\
\text { Yes }\end{array}$ & $\begin{array}{l}\text { Yes } \\
\text { Yes } \\
\text { Yes }\end{array}$ \\
\hline $\begin{array}{l}\text { Adjusted } R \text {-squared } \\
\text { Observations }\end{array}$ & $\begin{array}{l}0.4983 \\
14,529\end{array}$ & $\begin{array}{l}0.4972 \\
14,529\end{array}$ & $\begin{array}{l}0.4984 \\
14,529\end{array}$ & $\begin{array}{l}0.4984 \\
14,529\end{array}$ & $\begin{array}{l}0.4986 \\
14,529\end{array}$ \\
\hline
\end{tabular}

Table 9 reports the effects of four additional channels through which social pressures may affect CEO compensation. We show that the social premium associated with the number of local CEOs remains after controlling for those alternative sources of social pressures. First, we examine the effect of the number of local social elites ${ }^{15}$ and the number of top wealth holders in the state on social premiums in CEO pay. According to the Conspicuous Consumption Theory of Veblen (1934) and Frank (2000), wealthy people often use luxury homes to display wealth and signal social status to their peers. Next, we examine the effect of the value of luxury homes (the $99^{\text {th }}$ percentile value of homes sold in the MSA) and the value of CEO homes (for a subsample of 523 executives who were CEOs in 2004; provided by Cronqvist, Makhija, and Yonker, 2012) on social premiums. We orthogonalize the number of local CEOs to each of those four alternative sources of social pressures and find that each source has an influence on CEO pay, while the pressures from local CEOs elevate CEO pay beyond these alternative sources.

The sample is comprised of S\&P 1500 firms between 1994 and 2005 with performance data through 2008 . The dependent variable is $\operatorname{Ln}(T D C 1)$ (total annual pay in ExecuComp, expressed in 2005 dollars). The number of nearby social elites is the number of people who are listed on the Social Register in 2004 and live within 60 miles of the firm's headquarters. The number of IRS top wealth holders is the number of high net worth people (above $\$ 1$ million) in each state, estimated by the US Internal Revenue Service (IRS) from estate tax return filings in 1998. Luxury home value is the $99^{\text {th }}$ percentile of the values of homes sold in the MSA where the corporate headquarters is located. Purchase price of CEO home is the purchase price of the CEO's home (Cronqvist, Makhija, and Yonker 2012). Residual of Ln(number of local CEOs) on Ln(number of nearby social elites) is the error term in a regression of $\operatorname{Ln}$ (number of local CEOs) on $\operatorname{Ln}$ (number of nearby social elites). Other residual terms are similarly defined. Economic, governance, and local variables are the same as in Table 2. Standard errors are clustered at the firm level when computing significance; $t$-statistics are given in parentheses below each reported coefficient. ***,**, and * denote $p$-values $\leq 0.01,0.05$ and 0.10 , respectively.

\footnotetext{
${ }^{15}$ Very few social elites are current CEOs. The average and median numbers of social elites in the local area are 1,356 and 272, respectively. 
Table 9. Other channels of social comparisons

\begin{tabular}{|c|c|c|c|c|}
\hline Test information & $\begin{array}{c}\text { Number of Social } \\
\text { elites } \\
\text { (1) } \\
\end{array}$ & \begin{tabular}{|c|} 
Number of IRS \\
top wealth holders \\
$(2)$ \\
\end{tabular} & $\begin{array}{c}\text { Luxury home } \\
\text { value } \\
(3) \\
\end{array}$ & $\begin{array}{c}\text { Purchase price of } \\
\text { CEO home } \\
(4) \\
\end{array}$ \\
\hline \multicolumn{5}{|l|}{ Social variables } \\
\hline Ln(number of nearby social elites) & $\begin{array}{l}0.0394 * * * \\
(5.68)\end{array}$ & & & \\
\hline $\begin{array}{l}\text { Residual of Ln (number of local CEOs) on } \\
\text { Ln(number of nearby social elites) }\end{array}$ & $\begin{array}{l}0.0702 * * * \\
(4.43)\end{array}$ & & & \\
\hline $\operatorname{Ln}$ (number of IRS top wealth holders) & & $\begin{array}{l}0.0792 * * * \\
(5.50)\end{array}$ & & \\
\hline $\begin{array}{l}\text { Residual of Ln (number of local CEOs) on } \\
\text { Ln(number of IRS top wealth holders) }\end{array}$ & & $\begin{array}{l}0.0670 * * * \\
(5.54)\end{array}$ & & \\
\hline Ln(luxury home value) & & & $\begin{array}{l}0.1118 * * * \\
(3.14)\end{array}$ & \\
\hline $\begin{array}{l}\text { Residual of Ln (number of local CEOs) } \\
\text { on Ln(luxury home value) }\end{array}$ & & & $\begin{array}{l}0.0496^{* * *} \\
(3.00)\end{array}$ & \\
\hline $\operatorname{Ln}($ purchase price of CEO home) & & & & $\begin{array}{l}0.1418^{* * *} \\
(4.66)\end{array}$ \\
\hline $\begin{array}{l}\text { Residual of Ln (number of local CEOs) } \\
\text { on Ln (purchase price of CEO home) }\end{array}$ & & & & $\begin{array}{l}0.1098^{* * *} \\
(4.00)\end{array}$ \\
\hline Economic variables (see Table 2) & Yes & Yes & Yes & Yes \\
\hline Governance variables (see Table 2) & Yes & Yes & Yes & Yes \\
\hline Local variables (see Table 2) & Yes & Yes & Yes & Yes \\
\hline Intercept & Yes & Yes & Yes & Yes \\
\hline Year fixed effects & Yes & Yes & Yes & Yes \\
\hline Fama-French 49 industry fixed effects & Yes & Yes & Yes & Yes \\
\hline Adjusted $R$-squared & 0.4984 & 0.4991 & 0.4446 & 0.4956 \\
\hline Observations & 14,529 & 14,464 & 9,585 & 2,693 \\
\hline
\end{tabular}

\section{CONCLUSIONS AND PRACTICAL IMPLICATIONS}

It is often attributed to greed that highly paid CEOs demand higher pay. The evidence presented in this paper suggests that the compensation for otherwise identical CEOs depends on the wealth level needed to maintain the CEO's status in various social circles. If there are compelling reasons for a company's headquarters to be located in a certain area, the board is also compelled to follow the social norm and award the social premium to its highly valuable CEO. Boards' collective actions will raise CEO pay through time and thus increase income inequality, until action is taken to address the issue. Our research provides an understanding that can lead policy makers, institutional investors, and boards to consider alternative actions (other than raising CEO pay and regulations) for addressing social pressure's contribution to rising CEO pay and income inequality. 


\section{AUTHOR INFORMATION}

Gregory L. Nagel, Ph. D. is an Assistant Professor of Finance in the Jennings A. Jones College of Business at Middle Tennessee State University. He earned his doctorate in Finance at Florida State University. Dr. Nagel has been published in the Financial Review, Journal of Real Estate Finance and Economics, and the Quarterly Journal of Business and Economics. He is cited by search professionals such as Claudio Fernandez-Araoz and has presented to Fortune 500 size firms' heads of executive recruiting. He has also presented papers at national and international conferences. His current research interests include executive succession and institutional investors.

Denise M. Leggett, Ph.D., CPA is an Assistant Professor of Accounting in the Jennings A. Jones College of Business at Middle Tennessee State University. She earned her doctorate in accounting at the University of Alabama and her Certified Public Accountant licensure in the state of Tennessee. Dr. Leggett has published in the Academy of Accounting and Financial Studies Journal, presented research papers at national conferences, and given Continuing Professional Education presentations for other CPAs. Her current research interests include executive compensation and real earnings management.

\section{ACKNOWLEDGEMENTS}

We thank James Ang and Jun Yang for their many contributions to this paper. In addition, we thank Hannah Bolte, Randall Campbell, Melanie Cao, Jaden Falcone, Michael Faulkender, Gerry Garvey, Eitan Goldman, ByoungHyoun Hwang, Edwards Lazear, Richard Mahoney (retired CEO from Monsanto Co.), Cassandra Marshall, Ron Masulis, Todd Milbourn, Laura Starks, Irina Stefanescu, Ralph Walkling, David Yermack, Julie Zhu, and seminar participants at Erasmus University, Indiana University, Mississippi State University and Washington University in St. Louis, and session participants at the 2009 China International Conference in Finance, the 2008 Financial Management Association meetings, and the FMA European meetings in Prague. We also thank the Council for Community and Economic Research for providing us with the data on cost of living index.

\section{REFERENCES}

Acharya, V., and P. Volpin. 2010. Corporate Governance Externalities. Review of Finance 14: 1-33.

Baranchuk, N., G. MacDonald, and J. Yang. 2011. The economics of super managers. Review of Financial Studies 24: 3321-68.

Bebchuk, L., and A. Cohen. 2005. The costs of entrenched boards. Journal of Financial Economics 78, 409-433.

Bebchuk, L., and J. Fried. 2004. Pay without performance: The unfulfilled promise of executive compensation. Cambridge, MA: Harvard University Press.

Bertrand, M., and S. Mullainathan. 2001. Are CEOs rewarded for luck? The ones without principals are. Quarterly Journal of Economics 116:901-32.

Bizjak, J., M. Lemmon, and L. Naveen. 2008. Does the use of peer groups contribute to higher pay and less efficient compensation? Journal of Financial Economics 90: 152-168.

Bizjak, J., M. Lemmon, and T. Nguyen. 2011. Are all CEOs above average? An empirical examination of compensation peer groups and pay design. Journal of Financial Economics 100: 538-555.

Core, J., R. Holthausen, and D. Larcker. 1999. Corporate governance, chief executive officer compensation and firm performance. Journal of Financial Economics 51: 371-406.

Coval, J., and T. Moskowitz. 2001. The geography of investment: Informed trading and asset prices. Journal of Political Economy 109 (4): 811-841.

Cronqvist, H., A. Makhija, and S. Yonker. 2012. Behavioral consistency in corporate finance: CEO personal and corporate leverage. Journal of Financial Economics 103: 20-40.

Edmans, A., X. Gabaix, and A. Landier. 2009. A multiplicative model of optimal CEO incentives in market equilibrium. Review of Financial Studies 22:4881-4917.

Engelberg, J., P. Gao, and C. Parsons. 2013. The value of a Rolodex: CEO pay and personal networks. Review of Financial Studies 26: 79-114.

Faulkender M., and J. Yang. 2010. Inside the black box: The role and composition of compensation peer groups. Journal of Financial Economics 96: 257-270.

Firebaugh, G., and L. Tach. 2005. Relative income and happiness: Are Americans on a hedonic treadmill? Working 
paper, Pennsylvania State University and Harvard University.

Frank, R. 2000. Luxury Fever: Money and Happiness in an Age of Excess (Princeton University Press, Princeton).

Gabaix, X., and A. Landier. 2008. Why has CEO pay increased so much? Quarterly Journal of Economics 123:49100 .

Gompers, P., J. Ishii, and A. Metrick. 2003. Corporate governance and equity prices. Quarterly Journal of Economics 118: 107-155.

Hagerty, M. 2000. Social comparisons of income in one's community: evidence from national surveys on income and happiness. Journal of Personality and Social Psychology 78: 764-771.

Hamermesh, D. 1975. Interdependence in the labour market. Econometrica 42: 420-429.

Hartzell, J., and L. Starks. 2003. Institutional investors and executive compensation. Journal of Finance 58: 23512374.

Hayes, R., and S. Schaefer. 2009. CEO pay and the Lake Wobegon effect. Journal of Financial Economics 94:28090 .

Hwang, B., and S. Kim. 2009. It pays to have friends. Journal of Financial Economics 93: 138-158.

Ivkovic, Z., S. Weisbenner. 2007. Information diffusion effects in individual investors' common stock purchases: covet thy neighbors' investment choices. Review of Financial Studies 20: 1327-1357.

Kaplan, S., and J. Rauh. 2011. Wall Street and Main Street: What contributes to the rise in the highest incomes? Review of Financial Studies 23:1004-50.

Kedia, S., and S. Rajgopal. 2009. Neighborhood matters: The impact of location on broad based stock option plans. Journal of Financial Economics 92: 109-127.

Kleinberg, J. 2001. Small-world phenomena and the dynamics of information. Advances in Neural Information Processing Systems (NIPS) 14.

Knyazeva, A., D. Knyazeva and R. Masulis. 2014. Effects of local director markets on corporate boards. Review of Financial Studies, forthcoming.

Kuhnen, C. M., and Niessen, A. 2012. Public opinion and executive compensation. Management Science 58: 12491272.

Liu, C., and D. Yermack. 2007. Where are the shareholders' mansions? CEOs' home purchases, stock sales, and subsequent company performance. Working paper, Cornell University and New York University.

Malloy, C. 2005. The geography of equity analysis. Journal of Finance 60: 719-755.

McBride, M. 2001. Relative income effects on subjective well-being in the cross section. Journal of Human Behavior and Organization 45: 251-278.

Mok, D., J. Carrasco, and B. Wellman. 2009. Does distance still matter in the age of the internet? Urban Studies 46: $27-47$.

Morse, A., V. Nanda, and A. Seru. 2011. Are incentive contracts rigged by powerful CEOs? Journal of Finance 66:1779-1821.

Murphy, K. 1999. Executive compensation, in Ashenfelter, O., and D. Card, eds.: Handbook of Labor Economics, Volume 3.

Murphy, K., and J. Zabojnik. 2004. CEO pay and appointments: A market-based explanation for recent trends. American Economic Review Papers and Proceedings 94:192-96.

Nguyen, B. 2012. Does the Rolodex matter? Corporate elite's small world and the effectiveness of boards of directors. Management Science 58: 236-252.

Oyer, P. 2004. Why do firms use incentives that have no incentive effects? Journal of Finance 59:1619-49.

Petersen, M. 2009. Estimating standard errors in finance panel data sets: comparing approaches. Review of Financial Studies 22: 435-480.

Pigou, A. 1920. The economics of welfare (Macmillan and Co., London).

Renneboog, L., and Y. Zhao. 2014. Director networks and takeovers. Journal of Corporate Finance 28: 218-234.

Seidl, C., S. Traub, and A. Morone. 2006. Relative deprivation, personal income satisfaction, and average wellbeing under different income distributions, in Mark McGillivray eds.: Inequality, Poverty and Well-Being (Palgrave Macmillan, Basingstoke): 66-90.

Urry, J. 2007. Mobilities (Polity Press, Cambridge).

Veblen, T. 1934. The Theory of the Leisure Class (Modern Library, New York).

Watts, D. 2004. Six Degrees: the Science of a Connected Age (W.W. Norton \& Company, New York). 


\section{APPENDIX A: DEFINITION OF VARIABLES}

\begin{tabular}{cl}
\hline \multicolumn{1}{c}{ Variable name } & \multicolumn{1}{c}{ Variable definition } \\
\hline Compensation variables & \\
\hline Ex-ante total annual pay (TDC1) & $\begin{array}{l}\text { The sum of salary, bonus, the total value of restricted stock granted, the total value of } \\
\text { stock options granted, long-term incentive payouts, and other compensation } \\
\text { (ExecuComp variable } T D C 1) .\end{array}$ \\
\hline
\end{tabular}

Social variables

\begin{tabular}{ll}
\hline Number of local CEOs & $\begin{array}{l}\text { The number of S\&P 1500 companies headquartered within } 60 \text { miles of the location of } \\
\text { the firm's headquarters. This count includes the firm itself. }\end{array}$ \\
\hline Number of Forbes 400 & $\begin{array}{l}\text { The number of individuals identified by Forbes Magazine annually as one of the } \\
\text { richest } 400 \text { Americans that live within } 60 \text { miles of the firm's headquarters. }\end{array}$ \\
\hline Number of nearby social elites & $\begin{array}{l}\text { The number of individuals who are listed in the } 2004 \text { Social Register and live within } \\
60 \text { miles of the firm's headquarters. }\end{array}$ \\
\hline Number of IRS top wealth holders & $\begin{array}{l}\text { The number of top wealth holders in the state where the firm's headquarters is } \\
\text { located, estimated by the US Internal Revenue Service (IRS) from estate tax return } \\
\text { filings in } 1998 .\end{array}$ \\
\hline Luxury home value & The $99^{\text {th }}$ percentile value for homes sold in the metropolitan statistical area (MSA). \\
\hline Economic variables & \\
\hline Market-to-book & $\begin{array}{l}\text { The ratio of the market value to the book value of equity } \\
\text { (Compustat: data25*data199/data216). }\end{array}$ \\
\hline Firm risk (ROA) & The standard deviation of ROA in the trailing five years. \\
\hline Firm risk (stock return) & The annualized standard deviation of monthly stock returns in the trailing five years. \\
\hline Sales & Compustat variable data12. \\
\hline ROA & Return on assets (Compustat: data237/data6). \\
\hline Stock return (TRS1YR) & The trailing year stock return (ExecuComp variable TRS1YR). \\
\hline
\end{tabular}

Governance variables

$\mathrm{D}(\mathrm{CEO}$ chairs the board $)$

$\mathrm{D}$ (long CEO tenure)
$\mathrm{D}$ (high \% of block ownership)

An indicator of 1 if the CEO serves as the chairman of the board; and 0 otherwise. An indicator of 1 if CEO tenure is longer than sample median; and 0 otherwise.

$\mathrm{D}$ (high \% of block ownership) $\quad$ An indicator of 1 if the percentage of shares held by blockholders (more than $5 \%$ of the outstanding shares); and 0 otherwise (Compact Disclosure).

\begin{tabular}{ll}
\hline $\begin{array}{l}\mathrm{D} \text { (high \% of institutional } \\
\text { ownership) }\end{array}$ & $\begin{array}{l}\text { An indicator of } 1 \text { if the percentage of shares held by institutions is greater than sample } \\
\text { median; and } 0 \text { otherwise (Compact Disclosure). }\end{array}$ \\
\hline $\mathrm{D}$ (high \% of insider ownership) & $\begin{array}{l}\text { An indicator of } 1 \text { if the percentage of shares held by insiders is greater than sample } \\
\text { median; and } 0 \text { otherwise (Compact Disclosure). }\end{array}$ \\
\hline $\mathrm{D}$ (high \% of inside directors) & $\begin{array}{l}\text { An indicator of } 1 \text { if the percentage of board members who are the firm's officers is } \\
\text { greater than sample median; and } 0 \text { otherwise (Compact Disclosure). }\end{array}$ \\
\hline $\mathrm{D}$ (more directors) & $\begin{array}{l}\text { An indicator of } 1 \text { if the number of directors is greater than sample median; and 0 } \\
\text { otherwise (Compact Disclosure). }\end{array}$ \\
\hline $\mathrm{D}$ (high GIM index) & $\begin{array}{l}\text { An indicator of } 1 \text { if the number of anti-takeover provisions (defined by Gompers, } \\
\text { Ishii, and Metrick 2003) is greater than sample median; and 0 otherwise. }\end{array}$ \\
\hline
\end{tabular}

\begin{tabular}{ll} 
Local variables & The living cost differential across U.S. urban areas for moderately affluent \\
Cost of living index & professionals (published by the Council for Community and Economic Research). \\
\hline $\begin{array}{l}\text { Local stock return less market } \\
\text { return }\end{array}$ & $\begin{array}{l}\text { The value weighted return }(T R S 1 Y R \text { ) of all firms headquartered within } 60 \text { miles of the } \\
\text { firm's headquarters less the CRSP value weighted market return }(V W R E T D) .\end{array}$ \\
\hline $\begin{array}{l}\text { Average lagged pay for local } \\
\text { CEOs }\end{array}$ & $\begin{array}{l}\text { The average ex-ante total pay of CEOs whose headquarters are located within } 60 \\
\text { miles of the firm's headquarters. CEO pay is lagged by one year. In the calculation } \\
\text { of average CEO pay, the CEO of interest is excluded. }\end{array}$ \\
\hline
\end{tabular}




\section{APPENDIX B: CORPORATE GOVERNANCE AND SOCIAL PREMIUMS}

Given that social premiums are the amount of CEO compensation in excess of that which can be explained by firm performance, risk, and local economic conditions, it is useful to examine how corporate governance affects the magnitude of social premiums. We look at the effect of eight conventional corporate governance measures on social premiums, first jointly, then individually. The results are available on request. Social premiums are higher at firms with a higher block ownership, a smaller board, and a lower GIM index; each of which indicates strong corporate governance. Social premiums are higher at firms with a higher fraction of inside directors. This finding can be interpreted as an outcome of weak corporate governance. However, because inside directors are more likely to belong to the same social circle and are thus more knowledgeable about the social norm, this finding can be an indication of a conformation to social norms by boards with deeper local roots. Overall, our untablulated results show that social premiums are awarded to top executives at a wide range of firms, especially at firms with strong corporate governance. One possible interpretation for this finding is that strong boards use high CEO pay to signal high CEO ability and thus greater firm value (Hayes and Schaefer, 2009). We agree with Acharya and Volpin (2010) in that in a labor market with scarce managerial talent, even a strong board has to conform to the market norm, in this case, to grant social premiums in order to motivate and retain the CEO. 